\title{
A Corpus-based Appraisal of Doubts and Certitudes in Cameroon English Newspaper Writing: Attitudes and Prospects
}

\author{
Julius M. Angwah \\ University of Yaounde 1
}

\begin{abstract}
Newspapers constitute an important medium of informational dispersal, especially in postcolonial multilingual Cameroon. Its language has direct implications on Cameroonians' interpretations and appreciations of events in their environments. Consequently, degree of truthfulness is extremely vital in news stories, in order to regulate facts, based on what is doubtful and what is certain, for purposes of civil order and serenity. In this paper, I investigated the effects of personal metadiscourse markers_ hedges and boosters_ in Cameroonian online newspaper writing and on readership. A corpus of 19 randomly selected inciting stories, from 9 leading newspapers in Cameroon, constituted the primary data. In addition, an interview was conducted for purposes of ascertaining authorship and readership. The corpus was subjected to the 2014 AntConc 3.4.4.w. software to obtain the frequencies, concordances and functions of pre-identified hedges and boosters. The findings revealed that Cameroon English newspapers are more likely to boost claims than hedge them and that such claims have significant effects on the Anglophone Cameroonians' interpretation and appreciation of events in the country.
\end{abstract}

Keywords: Corpus-Based Study, Doubt and Certitude, Writing, Cameroon, Attitude and Prospects DOI: $10.7176 / \mathrm{NMMC} / 85-01$

Publication date: November $30^{\text {th }} 2019$

\subsection{Introduction and Background}

Information is central to communal growth and newspapers constitute an important medium of informing local and international readers on the state of events in the country and the world at large. The newspaper is generally understood as a daily or weekly publication of local and international news stories, opinions, advertisement, announcement and television listings. Researchers and scholars agree that it is an important medium of informational broadcasting in almost every community in the world (Borget 1981, Aitchison 1988, 2006, Babalola 2002, Biber 2003, and Anaeto et al 2009). Consequently, newspaper information must necessarily be "objective" and "subtle", since it tilts public agenda towards "sensitive topics" (Schoenbach 2005:1).

Interestingly, the objectivity of every newspaper story depends largely on the story-teller's skills in efficiently situating broad conceptual categories on a truth-value continuum in order to avoid what Lakoff (1972:458) describes as "vague boundaries and fuzzy edges". This is basically because if a news story is over hedged, it lacks credibility, and if it is over boosted, it may ignite civil disobedience or, at best, labeled the author as impolite (Caffi 1999:12). In fact, some high level personalities and even government bodies have vented outburst resentment towards newspaper authors and editors, based on their dissatisfaction on the boosting nature of reports. According to The Observer (29 Dec 2002), quoted in Aitchison (2006: 1), Prince Charles - the heir apparent to the throne of England - is noted to have described the newspaper as an "awkward, cantankerous, cynical, bloody-minded, at times intrusive, at times inaccurate, and, at times, deeply unfair and harmful to individuals and to institutions." Such outburst anger has been typical of antipathetic antagonism towards newspapers over the years. Most recently in Cameroon, journalists have been arrested and brutalised for publishing stories that unearth the stealthy dealings of some top government officials.

In Cameroon, as perhaps in most other countries of the world, while most victims of newspaper stories have been celebrities and influential personalities, we cannot fairly lose sight of the likely devastating encroachment should newspaper writers out rightly present the Cameroonian people, or the existing marginalized Anglophone community in Cameroon as the victims of the subjective decisions and the heretical actions of the ruling class. The likely effects may be monumental, especially in the current postcolonial multicultural Cameroon, marked by poverty and an uncompromising desire for economic survival, and also bounded by neighbors who have known the bitter realities of civil violence, partly ignited by newspaper propagandas. An effective ascription, therefore, of degree of truthfulness in the presentation of various propositions is extremely important for appropriate public appreciation of news stories in the country. Consequently, in this study, I explore the nature of newspaper writing from the perspective of degree of mitigation and commitment in the stating of certain propositions as well as the effects the levels of mitigation could have on readership among the Anglophone population in the country.

\subsection{Doubt and Certitude}

Hedges and boosters are often used to mitigate propositions, in terms of degree of confidence or diffidence in formal writing, and such usage could well indicate authors' levels of uncertainty and certainty. Hedges and 
boosters function more or less as regulators of claims and pointers of writers' degree of commitments to their propositions. In fact, they are unavoidable in formal writing.

Hedging is central to scientific argument, since it is the means by which scientists convey an attitude to their statements (Hyland 1995:1). Basically, hedges mitigate writers' certitudes and, ultimately, reduce their commitment to specific propositions. From the inception of the term in the early 1970s, it has grown from a "fuzzy concept" (Lakoff 1972:471) to a "convention of academic style" (Hyland 1998:27). It was first introduced in the literature by Lakoff (1972) to refer to words that make meaning fuzzy or fuzzier. Over the years, it has grown to be an almost unavoidable technique in academic writing and often judged as a mark of academic competence. Hyland (1998:2) maintains that writers often hedge to negotiate ideas and persuade their readers, yet giving them the chance to judge the claims for themselves. That is, giving them the chance to access the truth values of propositions. Hedges thus attenuate propositions with the intention of effectively situating concepts within broad conceptual categories either to show the writer's non-commitment to propositions or to reinforce the writer's precision. Hyland (1995:33) concludes that "hedging is the expression of tentativeness and possibility in language use". This means that it, often, subjects the veracity of claims to "subjective assessment" (opcit).

Unlike hedging, booster is at the other end of the continuum and constitutes an independent genre in the literature of contemporary academic rhetorical practices. Fundamentally, the conception stems from Lakoff's (op cit) second function of hedges - which is that of reinforcement of an author's conviction in various propositions. Writers use this technique to show their conviction in various propositions. This is why Hyland (1995:33) argues that boosters, such as clearly, obviously, and of course, permit writers to express conviction and assert to their claims with confidence.

Hedges and boosters are key techniques in formal writing. Borrowing from Hyland (op cit), they are effective strategies for "increasing or reducing the force of statement". The implication here is that the manipulation of expressions - through the effective use of boosters and hedges - exudes more reliable information to the public and limits the possibility of discordancy. This raises certain doubts, including the frequency of such mitigating devices in Cameroon English newspapers as well as the effects they could have on Anglophone newspaper reading audience in the country.

\subsection{Literature Review}

Newspaper writing has been a longstanding culture in human social interaction. Historically, it has grown from a traditional ballad to a more technologically advanced channel of communication within local and international communities (Aitchison: 2006:4). The importance of newspaper, therefore, is based on the fact that its news stories have direct application to peoples' daily societal quests. Galtung and Ruge (1999) highlight a few characteristics of newspaper stories, including recency (any happening within 24 hours), proximity (nearness of the news to the socio-economic life of the people), negativity (bad news is more appreciated), unexpectedness (sudden shocking events) and person-centeredness (individuals or institutions to blame). These features have been confirmed in later studies as typical of newspaper stories (Waal 2005, INEY 2008, Anaeto et al. 2009, Shanon 2010 and Dhanushka 2010).

Since newspapers seek to influence public opinions on different socio-political and moral issues, evaluative connotative vocabulary often abound this form of writing. Thus, the indispensability of the newspaper as a tool for communal update has received elaborate attention in the literature. Onu (2005:1), for instance, remarks that the newspaper is perhaps the fastest transmitter of current information and it is fairly considered the most conservative and prevalent means of transmitting divisional, regional, national and international news. It was on this basis that, Babalola (2002) argued that if newspaper stories are not objective, they could either make or mar civil order. Though this claim was made within the context of the growing reading population of Nigeria, it is likely to be true of Cameroon, which, observably, now has a growing online-reading population with the digital advancement of newspaper publications. With the current politico-economic threats that now faces Cameroon, the probability of newspapers inducing the Cameroonian Anglophone youths is relatively higher, especially with online versions of newspaper stories and the advent of smart phones and such common apps as Facebook, Watsapp and Twitter which readily makes available incisive news stories to the vast "android" youthful population. With such observations, it is important to first of all find out the extent to which authors' of newspaper stories express doubts and certitudes in their presentations of various propositions and second find out the extent to which the nature of newspaper writing (in terms of degree of mitigation and commitment to claims) has on the youthful Anglophone growing reading population in Cameroon.

\subsection{Data and Methods}

\subsection{Materials}

In order to achieve the purpose of this study, we obtained a corpus of 19 inciting stories from 9 online leading newspapers in Cameroon. Our choice of inciting stories was purposeful, since, depending on the degree of 
certitude and manner of presentation, they can regulate readers' construal of stories and either enflame or repress their emotions in the appreciation of the news. The stories, that were considered, addressed issues, related to minority questions, especially the Anglophone question, as well as top government officials' overindulgences. Generally, we had 24496 words as can be summarised on the table below.

\begin{tabular}{|c|c|c|c|c|}
\hline No & Newspaper & Selected Stories & Authors & No. Wds \\
\hline \multirow[t]{2}{*}{1} & The & Truth that must be told & The Guardian Post & \multirow[t]{2}{*}{2256} \\
\hline & $\begin{array}{l}\text { Guardian } \\
\text { Post }\end{array}$ & Cult greeting signs identified within PCC & The Guardian Post & \\
\hline \multirow[t]{3}{*}{2} & Berate & The Anglophone Problem is Unique & Berate News & \multirow[t]{3}{*}{7,762} \\
\hline & News & Anglophone Lawyers' Ultimatum & Berate News & \\
\hline & & Is Victor Ngo and Anglophone? & Berate News & \\
\hline \multirow[t]{2}{*}{3} & $\begin{array}{l}\text { Eden } \\
\text { Newspaper }\end{array}$ & $\begin{array}{l}1^{\text {st }} \text { October Headlines \& Hiccups_ NW \& SW in } \\
\text { Undeclared State of emergency }\end{array}$ & Solomon Tembang & \multirow[t]{2}{*}{2,741} \\
\hline & & Cameroon's Huge Debt Alarms IMF & Elias Ntungwe Ngalame & \\
\hline \multirow[t]{2}{*}{4} & Bamenda & ENAM Results Scandal: PAP Reacts & Akoson A. Raymond & \multirow[t]{2}{*}{1,489} \\
\hline & Online & Detained SCNC Activists to be Arraigned July 26 & Bamenda Online & \\
\hline \multirow[t]{2}{*}{5} & $\begin{array}{l}\text { Cameroon } \\
\text { Post }\end{array}$ & $\begin{array}{l}\text { CPDM Reconciliation Confab Flops, Money- } \\
\text { Doublers Accused Of Hijacking Party }\end{array}$ & Maxcel Fokwen & \multirow[t]{2}{*}{1865} \\
\hline & & Lawyers Slam Gov’t, Extend Strike & Bouddih Adams & \\
\hline \multirow[t]{2}{*}{6} & The Eye & Who Killed Dele Giwa? & Bayo Oluwasanmi & \multirow[t]{2}{*}{2,554} \\
\hline & & $\begin{array}{l}\text { President of National Episcopal Conference } \\
\text { Urges Paul Biya to relinquish }\end{array}$ & The Eye & \\
\hline \multirow[t]{3}{*}{7} & Post Watch & $\begin{array}{l}\text { Kah Walla: Camerounese Opposition: Failure of } \\
\text { Vision and Leadership }\end{array}$ & $\begin{array}{l}\text { Ntemfac } \\
\text { Aloysius }\end{array}$ & \multirow[t]{3}{*}{3,835} \\
\hline & & $\begin{array}{l}\text { The Difficulties of Minorities in Cameroon: } \\
\text { Cameroonian Homosexual in Asylum Battle }\end{array}$ & Elie Smith & \\
\hline & & $\begin{array}{l}\text { Understanding The Bello Bouba/UNDP } \\
\text { "Betrayal" }\end{array}$ & Dibussi Tande & \\
\hline \multirow[t]{2}{*}{8} & $\begin{array}{l}\text { The } \\
\text { Rambler }\end{array}$ & $\begin{array}{l}\text { Bid to Rescue Anglophone Cultural Values: } \\
\text { Cameroon Education Forum Created }\end{array}$ & Jean Marie Ngong Song & \multirow[t]{2}{*}{1,444} \\
\hline & & $\begin{array}{l}\text { Members of Parliament Tagged as SCNC } \\
\text { Stalwarts }\end{array}$ & Jean Marie Ngong Song & \\
\hline \multirow[t]{2}{*}{9} & The Sun & $\begin{array}{l}\text { University of Buea: Students March to thank Mr } \\
\text { Biya for Promised Laptops }\end{array}$ & The Sun & 550 \\
\hline & & Total & & 24496 \\
\hline
\end{tabular}

\section{Table 1: Composition of News Stories from 9 Online Cameroonian Newspapers}

The 19 stories were read closely and words and phrases that suggested doubts and certitudes were identified for eventual analyses. The corpus was then subjected to the 2014 AntConc 3.4.4.w. software to obtain the contexts and frequencies of identified hedges and boosters. While so many mitigating devices were identified in the corpus, we limited the scope to those that were relatively recurrent. Basically, therefore, we identified the following hedges in the corpus: epistemic modal auxiliaries (may, might, could and would), epistemic evidential verbs (seem, tend and appear), judgment verbs (think, propose, speculate suggest and indicate), epistemic adverbs (Usually, probably, apparently, possibly, in most cases, perhaps, typically, in my opinion, and in my view), epistemic adjectives (possible, likely, sure, and probable), epistemic nouns (possibility, assumption and probability), and approximators (about, approximately, some, and around), and such phrases as it is not quite clear whether, we are not sure if as well as the use of conditional "if" in introducing propositions. With regards to boosters, we noticed the use of in fact, certainly, definitely, it is clear that, undoubtedly, clearly, obviously, must, should, have to, substantially, exclusively, significantly, and of course as well as such fragments as it is clear that..., there is no doubt that..., we cannot ignore the fact that... it is quite clear that and it is important to note that...

In the analyses of data, the concordances of every linguistic variable were studied closely before consideration. This was so because not all the above linguistic variables always occur in the mitigating sense as it is the case of "can", a canister, and an epistemic modal auxiliary. The process of data analyses and presentation of results was guided by the quantitative and qualitative techniques of the corpus-based methodology.

Additionally an interview was conducted in the Anglophone city of Bamenda, North West Region of Cameroon, to ascertain newspaper writers' motives for hedging and boosting propositions and also to describe the degree of effects the mitigation of newspaper stories could have on the growing Anglophone newspaper 
audience. There were two categories of informants - newspaper authors and newspaper readers. 6 newspaper authors were asked three questions:

1. Are you always certain of the ideas you write in your stories or those in stories you edit for publication?

2. Do you think you create an effect in your readers whenever you write the way you do?

3. Can the force of newspaper information bring about any form of change in the country?

200 newspaper readers (all of whom were between the ages of 20 and 35 and were all faithful readers of the online alternatives of the printed newspapers we considered for analysis) were also asked three questions:

1. Do you believe in the news you read from the papers?

2. Do you sometimes feel proud or sad after reading certain inciting stories from the papers?

3. Can the force of newspaper information bring about any form of change in the country?

\subsection{Results}

\subsection{The Expression of Doubt in Newspaper Writing in Cameroon} Epistemic Modal Auxiliaries

Epistemic modal auxiliaries (may, might, could, would) are often considered the most frequent hedging devices in most formal writings. Even so, they were not quite recurrent in the Cameroon English newspapers as could be seen on the following table.

\begin{tabular}{|c|c|c|}
\hline Epistemic Modal Auxiliaries & Frequency & Percentage \\
\hline May & 10 & $27.58 \%$ \\
\hline Might & 8 & $22.85 \%$ \\
\hline Could & 11 & $31.43 \%$ \\
\hline Would & 6 & $17.14 \%$ \\
\hline Total & 35 & $100 \%$ \\
\hline
\end{tabular}

\section{Table 2: Epistemic Modal Auxiliaries}

Though epistemic modal auxiliaries occurred just 35 times in the corpus, epistemic could was the most frequent, with a slim margin to may and might. In the corpus, may occurred in two ways_first, in the epistemic sense as seen in (1) and (2), and then as the month of a year, but the later occurrence was not considered, since it doesn't express an epistemic sense. All occurrences of might in the corpus were epistemic. Could occurred in two ways, as a tone-down device, (5) and (6), and as the past tense marker of can while would occurred in the epistemic sense and as the past tense marker of will. Below are some examples of epistemic modalities in the corpus.

(1) Guilty gay parties may go to jail for up to six years.

(2) While Cameroon may have a record 150 parties, the bottom line is that all these parties fall within three broad ideological blocs.

(3) According to the CATTU Executive secretary, such allegations of a petition on him might be true or false.

(4) The regime is careful to create an English CRTV channel because it might empower the Anglophones and probably develop more sense of an independent Southern Cameroon.

(5) Mr Biya's decision to ignore the Anglophone problem could eventually raise serious nationality questions in future.

(6) The lawyers protest could evidently spark a revolution in other areas where Anglophones feel cheated.

(7) With such scandal, it would appear the much expected change is just around the corner.

Generally, in all cases, epistemic may did not collocate with other tone-down devices as it is the case with might in (3) which is emphasised by the reference to CATTU executive secretary, or the case of could in (6) which is further strengthened by the epistemic adverb, evidently. It is important to remark that the reference to CATTU executive secretary in (3) shifts the responsibility of the claim to the secretary, since the writer is only reporting what the secretary has said. In general, epistemic modalities function as tone-down devices and suggest the degree of certainty of propositions.

Epistemic Evidential and Judgement Verbs

Tables 3 and 4 present the distribution of epistemic evidential and judgmental verbs in the corpus.

\begin{tabular}{|c|c|c|}
\hline Epistemic Evidential Verbs & Frequency & Percentage \\
\hline seem & 3 & $42.86 \%$ \\
\hline tend & 1 & $14.28 \%$ \\
\hline appear & 3 & $42.86 \%$ \\
\hline Total & 7 & $100 \%$ \\
\hline
\end{tabular}

Table 3: Epistemic evidential verbs 


\begin{tabular}{|c|c|c|}
\hline Epistemic Judgement Verbs & Frequency & Percentage \\
\hline Think & 11 & $100 \%$ \\
\hline propose & 00 & $00 \%$ \\
\hline speculate & 00 & $00 \%$ \\
\hline suggest & 00 & $00 \%$ \\
\hline indicate & 00 & $00 \%$ \\
\hline Total & 11 & $100 \%$ \\
\hline
\end{tabular}

Table 4: Epistemic Judgement verbs

Generally, the occurrence of epistemic evidential verbs was not very significant, considering that seem and appear occurred three times, while tend occurred just once. Interestingly, with regards to judgement verbs, just think occurred in the corpus. The following are some textual examples.

(8) Many Cameroonians seem genuinely surprised at (and outraged) Bello Bouba's most recent alliance with the CPDM, at the expense of the opposition front that boycotted the October presidential elections.

(9) Ndam Njoya's strong personality and independent streak tend to mask the fact that his party is essentially another holdout for members of the neo-conservative bloc who never accepted Bello Bouba as a worthy heir to the Babatoura.

(10) So I think the move the lawyers took was very correct.

(11) I think Mr President and his officials are people with a colonial mentality.

While seem in (8) reduces the degree of certitude of the claim, expressed, genuinely, seems to suggest that even though the writer is uncertain about the claim, he is sure it is more likely to be true than false. Interestingly, all the occurrences of think are preceded by the first person singular pronoun, I. This denotes a binary uncertainty, since $I$, restricts the truth to the writer and think further lessens the relative truth value of the claim, expressed.

\section{Epistemic Adverbs}

Primarily, epistemic adverbs, like most other epistemic devices, comment on propositions. Nkemleke (2011:27) remarks that writers who use such forms are involved in the same mental process of deduction and judgement about the certainty, reliability, and limitations of such propositions. The distribution of epistemic adverbs in the corpus can be seen in table 5 .

\begin{tabular}{|c|c|c|}
\hline Epistemic Adverbs & Frequency & Percentage \\
\hline Usually & 3 & $27.27 \%$ \\
\hline probably & 4 & $36.37 \%$ \\
\hline apparently & 1 & $9.09 \%$ \\
\hline possibly & 00 & $00 \%$ \\
\hline in most cases & 00 & $00 \%$ \\
\hline perhaps & 1 & 9.09 \\
\hline typically & 00 & $00 \%$ \\
\hline in my opinion & 2 & $18.18 \%$ \\
\hline in my view & 00 & $00 \%$ \\
\hline Total & 11 & $100 \%$ \\
\hline
\end{tabular}

\section{Table 5: Epistemic Adverbs}

Though the occurrences of epistemic adverbs were not significant, possibly, in most cases, and typically did not occur at all in the corpus. Generally, in all cases of epistemic adverbial occurrences, they functioned as moderators of claims and thus help to emphasise the uncertainties of propositions. Below are some textual examples.

(12) It should be pointed out also that the most prominent members of this party who have jumped ship since its creation have usually joined the UNDP or returned to the CPDM

(13) When it finally explodes, probably, most of them and their children abroad would have died.

(14) The North West and South West regions were on 1 October apparently in a state of undeclared state of emergency.

(15) Perhaps the message is unclear to the regime in power.

(16) In my opinion, adding debt burden to an already wrecked system may only make the reckoning more painful.

\section{Epistemic Adjectives}

Epistemic adjectives are also often used to tone-down the force of statement or indicate level of truthfulness of stated propositions. 


\begin{tabular}{|c|c|c|}
\hline Epistemic Adjectives & Frequency & Percentage \\
\hline Possible & 2 & $25 \%$ \\
\hline likely & 2 & $25 \%$ \\
\hline sure & 4 & $50 \%$ \\
\hline probable & 00 & $00 \%$ \\
\hline Total & 8 & $100 \%$ \\
\hline
\end{tabular}

Table 6: Epistemic Adjectives

Noticeably, probable did not occur in the corpus and the occurrences of possible, likely and sure were not very significant, though sure occurred more. Consider the following contextual examples.

(17) Africa Top Secret not only reveal that a group claiming to be composed of 173 civil society organisations has been looking for a possible leader but the group actually has proposed names.

(18) It is common knowledge that those most likely to have their rights savaged in Cameroon are the minority Anglophones.

(19) I am sure that if the English speaking part of Cameroon were independent, that area would have been far more developed than what we have today.

The truth value of the proposition in example (18) is regulated by most likely. Though most is a booster, it modifies likely, and thus shifts the certitude of the proposition further up the truth value continuum. Notably, the three epistemic nouns, possibility, assumption, and probability which were tested did not occur in the corpus.

\section{Approximators}

Generally, approximators are used to state uncertain figures or numbers in formal writing. Fraser (2010:19) argues that approximators operate on the propositional content proper and contribute to the interpretation class membership of a particular item. Though he makes reference to two types of approximators_ADAPTORS (what Lakoff (1972) refers to as hedges) and ROUNDERS which is that of quantification_we were interested in the later understanding of approximators. Table 7 presents the distribution of the tested approximators in the corpus.

\begin{tabular}{|c|c|c|}
\hline Approximators & Frequency & Percentage \\
\hline about & 2 & $4.54 \%$ \\
\hline approximately & 1 & $2.27 \%$ \\
\hline some & 41 & $93.19 \%$ \\
\hline around & 00 & $00 \%$ \\
\hline Total & 44 & $100 \%$ \\
\hline
\end{tabular}

\section{Table 7: Approximators}

Remarkably, some was the most frequent approximator in the corpus, relative to about, approximately and around which were not frequent. In fact, Epistemic around did not occur at all. Based on the relatively high frequency of some, it was necessary to closely examine some contextual examples in the corpus.

(20) It should be recalled that in December 1999 some members of the SCNC hijacked CRTV Buea and broadcast a message declaring the independence of Southern Cameroons.

(21) Some 16 persons accused of holding a meeting without authorisation, who were arrested in the Molyko neighbourhood on July 16, will be arraigned in court today, July 26.

The approximator, some, was used in two different ways in the corpus. First, it was used to mark numerical uncertainty as in example 20 and secondly it was used as a pre-modifier as seen in example 21 . While these two usages were relatively recurrent, the former was at $63.42 \%$, while the latter was as $36.58 \%$.

\section{Mitigating Clauses as Hedges}

There were a few clauses that function as hedges. The following are some of the fragments which were observed to be relatively recurrent in the corpus:

\begin{tabular}{lll}
\hline Mitigating Clauses as Hedges & Frq. & \% \\
\hline it is not quite clear whether & 13 & $22.41 \%$ \\
we are not sure if & 26 & $44.82 \%$ \\
If clauses & 19 & $32.75 \%$ \\
\hline
\end{tabular}

Table 9: Mitigating Clauses as Hedges

These fragments were used to indicate the authors' uncertainties of propositions as well as techniques to distant themselves from the veracity eminent in various propositions. Consider, for instance, the following textual occurrences of the above variables,

(22) It is not quite clear whether, with the growing unrest in the two English regions of the country, government is ready for inclusive dialogue.

(23) As at now, we are not sure of the fate of the arrested Anglophone protesters. 
(24) If there is any willingness to restore peace in the country, then the time of dialogue cannot be any other time than now.

Summarily, the general occurrences of hedges are presented on table 8 .

\begin{tabular}{|c|c|c|c|}
\hline No & Hedges/ Types & Frequency & Percentage \\
\hline 1 & Epistemic Modal Auxiliaries & 35 & $15.08 \%$ \\
\hline 2 & Epistemic Evidential and Judgment Verbs & 7 & $3.01 \%$ \\
\hline 3 & Epistemic Verbs & 11 & $4.74 \%$ \\
\hline 4 & Epistemic Adverbs & 11 & $4.47 \%$ \\
\hline 5 & Epistemic Adjectives & 8 & $3.44 \%$ \\
\hline 6 & Epistemic Nouns & 00 & $00 \%$ \\
\hline 7 & Approximators & 44 & $18.96 \%$ \\
\hline \multirow[t]{2}{*}{8} & Mitigating Clauses as Hedges & 58 & $25 \%$ \\
\hline & Total & 232 & $100 \%$ \\
\hline
\end{tabular}

\section{Table 8: Overall Occurrences of Hedges}

Relatively, mitigating clauses as hedges were the most frequent hedges in the corpus, slightly more frequent that approximators. On the whole, the others occurred less frequently.

\subsection{The Expression of Certitudes in Newspaper Writing in Cameroon}

Unlike hedges, boosters were quite recurrent in the corpus. Consider, for example the following distribution of boosters on table 9 .

\begin{tabular}{llll}
\hline No & Boosters & Frequency & Percentage \\
\hline $\mathbf{1}$ & In fact & 45 & $11.56 \%$ \\
$\mathbf{2}$ & certainly & 32 & $8.22 \%$ \\
$\mathbf{4}$ & definitely & 15 & $3.85 \%$ \\
$\mathbf{5}$ & it is clear that & 26 & $6.68 \%$ \\
$\mathbf{6}$ & undoubtedly & 7 & $1.79 \%$ \\
$\mathbf{7}$ & obviously & 38 & $9.76 \%$ \\
$\mathbf{8}$ & must & 27 & $6.94 \%$ \\
$\mathbf{1 0}$ & have to & 30 & $7.71 \%$ \\
$\mathbf{1 1}$ & substantially & 33 & $8.48 \%$ \\
$\mathbf{1 2}$ & exclusively & 1 & $0.25 \%$ \\
$\mathbf{1 3}$ & significantly & 8 & $2.05 \%$ \\
$\mathbf{1 4}$ & of course & 2 & $0.51 \%$ \\
$\mathbf{1 5}$ & it is clear that..., & 36 & $9.25 \%$ \\
$\mathbf{1 6}$ & there is no doubt that..., & 33 & 8.48 \\
$\mathbf{1 7}$ & we cannot ignore the fact that... & 7 & 3.85 \\
$\mathbf{1 8}$ & it is quite clear that... & 23 & 1.79 \\
$\mathbf{1 9}$ & it is important to note that... & 11 & 5.91 \\
\hline
\end{tabular}

\section{Table 9: Relative Frequencies of Boosters}

In fact, occurred more frequently, slightly more so than clearly. Substantially and significantly were the least occurrences in this category. This shows newspaper authors' higher degree of commitment, since boosters generally emphasise the force of claims, suggesting the writers' conviction to the claims they make and thus limit readers' chances of disputing the veracity of the propositions. The following are a few contextual examples of some of the above variables.

(25) In fact, today, hordes of Anglophones have fled to the Diaspora; fleeing from economic and outright genocide as practiced by their own government.

(26) He is, in fact, the diaspora president.

(27) ... Delphine Tsanga, another Ahidjo favorite, should ultimately throw in her lot with the UNDP and not with the SDF.

(28) Therefore, we could see clearly that the decree which created UB endorses bias admission process of Anglophones into the institution.

(29) Such gestures are, of course, open display of marginalization

(30) It is quite clear that government is determined to violently enforce a peaceful co-existence. 
Table 9 and figure 1 summarise the frequency of both hedges and boosters in the corpus

\begin{tabular}{lll}
\hline Metadiscourse markers & Frequency & Percentages \\
\hline Hedges & 232 & $37.35 \%$ \\
Boosters & 389 & $62.65 \%$ \\
Total & $\mathbf{6 2 1}$ & $\mathbf{1 0 0 \%}$ \\
\hline
\end{tabular}

Table 9: relative frequency of hedges and boosters

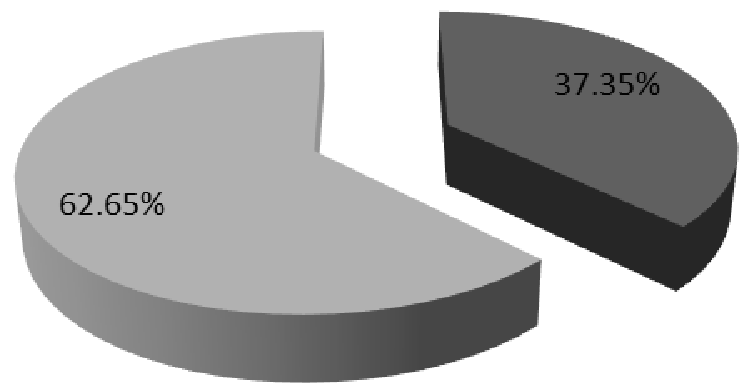

Figure One: Relative Frequency of Hedges and Boosters in Cameroon English Newspapers

The above statistic indicates that Cameroon English newspaper writers are more likely to boost their propositions than hedge them. The questions that quickly come up is what accounts for Cameroon English newspaper writers' motives for boosting and hedging claims and the extent to which their mitigation of newspaper propositions affects readership. The following tables summarise the 6 newspaper writers' opinions about the expression of doubt and certitude in newspaper writing in the country, as well as the 200 informants' responses on the effects newspapers have on their interpretations and appreciations of events in the country.

\begin{tabular}{|c|c|c|c|c|c|c|}
\hline Questions to Newspaper Writers & Yes & No & $\mathbf{Y} / \mathbf{N}$ & Frq. & $\%$ & T. \\
\hline $\begin{array}{l}\text { Are you always certain of the facts you write in } \\
\text { your stories or those in stories you edit for } \\
\text { publication? }\end{array}$ & 3 & 0 & 2 & 6 & $\begin{array}{l}\mathrm{Y}(60 \%) \\
\mathrm{Y} / \mathrm{N}(40 \%)\end{array}$ & $6(100 \%)$ \\
\hline $\begin{array}{l}\text { Do you think you create an effect in your readers } \\
\text { whenever you write the way you do? }\end{array}$ & 6 & 0 & 0 & 6 & $Y(100 \%)$ & $6(100 \%)$ \\
\hline $\begin{array}{l}\text { Can the force of newspaper information bring } \\
\text { about any form of change in the country? }\end{array}$ & 6 & 0 & 0 & 6 & $Y(100 \%)$ & $6(100 \%)$ \\
\hline
\end{tabular}

Table 10: Newspaper Writers' Motives for Expressing Doubts and Certitudes in Writing

\begin{tabular}{|c|c|c|c|c|c|c|}
\hline Questions to Newspaper Readers & Yes & No & $\mathbf{Y} / \mathbf{N}$ & Frq & $\%$ & $\mathbf{T}$. \\
\hline $\begin{array}{l}\text { Do you believe in the news you read from the } \\
\text { papers? }\end{array}$ & 189 & 0 & 11 & 200 & $\begin{array}{l}\mathrm{Y}(94.5 \%) \\
\mathrm{Y} / \mathrm{N}(5.5 \%)\end{array}$ & $\begin{array}{l}200 \\
(100 \%)\end{array}$ \\
\hline $\begin{array}{l}\text { Do you sometimes feel proud or sad after reading } \\
\text { certain inciting stories from the papers? }\end{array}$ & 200 & 0 & 0 & 200 & $Y(100 \%)$ & $\begin{array}{l}200 \\
(100 \%)\end{array}$ \\
\hline $\begin{array}{l}\text { Can the force of newspaper information bring } \\
\text { about any form of change in the country? }\end{array}$ & 195 & 0 & 5 & 200 & $\begin{array}{l}\mathrm{Y}(97.5 \%) \\
\mathrm{Y} / \mathrm{N}(2.5 \%)\end{array}$ & $\begin{array}{l}200 \\
(100 \%)\end{array}$ \\
\hline
\end{tabular}

Table 11: Effects of Newspaper Authorship on Readership

The above results suggest that newspaper writers are not completely certain about the facts they write or edit, even though they boost them. Interestingly, the relative percentage $(94.5 \%)$ of readers who believe in stories they read in the papers is significantly high. In fact, the remaining $5.5 \%$ of the informants actually said they do not totally believe every story, which means they believe some. It is gripping to notice that while newspaper writers' intention is to influence the readers' interpretation of their environment, the readers too seem totally influenced by this. Both groups share the belief that the force of newspaper writing can enhance change in the country. The few readers $(2.5 \%)$ who felt that it may or may not $(\mathrm{Y} / \mathrm{N})$ enhance change in the country based their arguments on the idea that most Cameroonians do not read and so if there is need for any kind informational distribution, other channels, especially the social media could be used to compliment newspaper stories. 


\subsection{Discussion and Conclusion}

The expression of doubt and certitude in newspaper writing is extremely important, especially with the emergence of digital mediums of informational transmission and with the current addiction among contemporary Cameroonian youths to this modern form of informational dispersal. The language of newspapers which are always readily available to this class of Cameroonians is unambiguously important for the regulation of youthful mentality. The current study has revealed that boosters abound Cameroon English newspaper writing, while hedges, for the most part, are under used. This corroborate the idea that that Anglophone Cameroonian newspaper writers write to thrill their readers and move them to action. Embarrassingly, the general picture is that in which committed Anglophone writers boost the predicaments of their people, while pro-government writers tend to boost counter discourses and even humanitarian and developmental efforts by government to build the country, thereby painting an almost undoubted circle of public deception.

Remarkably, the results are frightening, considering that all the newspaper readers, considered for this study, were between the ages of 20 and 35. Notably, the desperation among this group of Anglophone youths in Cameroon is sadly appalling. The relative percentage of boosters, which does not only denote confidence in what is reported, but leaves the readers with a very slim chance to contest the claims, was $62.65 \%$, with different boosting devices richly in use. This was markedly not the case with hedges which occurred $37.35 \%$. In fact, this distribution of hedges and boosters has a significant (97.5\%) effect on the readers' analysis of the news, since they begin with the belief that the stories are true. Notably, the popular credence that Cameroonian youths do not read is highly exaggerated, since the comments on inciting news stories on Facebook, watsapp and twitters are often quite significant, especially when the news are recent, negative and inciting. Considering the observable patent socio-economic challenges that characterise the daily experiences of this category of Cameroonians, and considering that boosters enhance a higher communicative solidarity (Holmes, 1984 \& 1990), it would not be surprising if some newspaper stories eventually spur a revolution in Cameroon, since for the most part, inciting news stories fall within the framework of what is often referred to, in journalistic language, as hard news, as opposed to soft news which happens over a longer period of time.

\section{References}

Aitchison, J. (1988). Writingfor thepress, London, Hutchinson.

Babalola, E.A. (2002). Newspapers as instruments for building literate communities: The Nigerian experience. Nordic Journal of African Studies 11(3), 403-410.

Biber, D. (2003). "Compressed noun phrase structures in newspaper discourse: the competing demands of popularization vs economy", in Aitchison and Lewis (2003b).

Caffi, C. (1999). “On mitigation'”. Journal of Pragmatics 31: 881-909.

Fraser, B. (2010). "Pragmatic Competence: the Case of Hedging." New Approaches to Hedging.

Galtung, J., Ruge, M. Holmbo (1965), 'The structure of foreign news', Reprinted in Tumber (1999).

Holmes, J. (1984) Modifying illocutionary force. Journal of Pragmatics, 8, 345-365.

Holmes, J. (1990). Hedges and boosters in women's and men's speech. Language and communication, 10 (3), $185-205$

Hyland, K. (1995). "The author in the text: hedging scientific writing."Hong Kong Papers in Linguistics and Language Teaching, 18, 33-42.

Hyland, K. (1998).Hedging in Scientific Research. Amsterdam: John Benjamins.

Lakoff, G. (1972). "Hedges: a Study in Meaning Criteria and the Logic of Fuzzy Concepts."Journal of Philosophical Logic, 2(1),458--508.

Shanon s. (2003). Review of always on: Language in an Online and Mobile world. Language Learning \& Technology. 14(3)19-22.

Schoenbach, K. (2005). Newspapers and their Impact on the extent of the perceived public agenda. European Journal of Communication 20, 2, 245-258

Nkemleke, D.(2011).Exploring Academic Writing in Cameroon English: A Corpus-Based Perspective.Göttingen: Cuvillier. 